This work is licensed under a Creative Commons Attribution 4.0 International License.

Ovaj rad dostupan je za upotrebu pod međunarodnom licencom Creative Commons Attribution 4.0.

Saša Stanić

\title{
(NE)MOGUĆNOSTI KNJIŽEVNOKRITIČKIH TEKSTOVA I NJIHOVO MJESTO NA TRŽIŠTU
}

Saša Stanić, Sveučilište u Rijeci, Filozofski fakultet, sstanic@ffri.hr, Rijeka

pregledni rad

UDK 82.09

rukopis primljen: 5. svibnja 2019; prihvaćen za tisak: 2. listopada 2019.

U uvodnom dijelu rada sagledavaju se neki od problema interpretacije književnogadjelapodutjecajempoststrukturalističkihidekonstrukcionističkih teorija u znanosti o književnosti. Rad se potom posvećuje pitanju statusa književne kritike u vremenu obilježenom vladavinom spektakla i tržišta, odnosno u kontekstu suvremene zbilje u kojem tekstovi (u najširem značenju riječi) egzistiraju na bitno drugačiji način nego što smo to kroz povijest pismenosti imali prilike svjedočiti. Primjeri kojim se potvrđuju iznijete teze dotiču se domaće književne i medijske scene, kao i prateće književnokritičke produkcije objavljivane u tiskanim medijima te na internetu i radiju.

Ključne riječi: interpretacija; književna kritika; vrijednost; kontingencija; društvo spektakla; tržište 


\section{O tekstu, tumačenju i dekonstrukciji}

Ali mislim da smo danas daleko barem od smiješne neskromnosti da iz našeg ugla dekretiramo kako se jedino iz tog ugla smije imati perspektive. Svijet nam je, štoviše, još jednom postao „beskonačnim”: utoliko što ne možemo odbaciti mogućnost da on u sebi uključuje beskrajne interpretacije (Nietzsche 2003: 219).

Klasik talijanske književnosti, Italo Calvino, u jednome svom tekstu postavlja pitanje za koga se pišu romani i pjesme? Na njega odgovara lapidarno: „Za osobe koje su pročitale neke druge romane, neke druge pjesme" (Calvino 2010: 359). Iako se Calvinov odgovor može učiniti pojednostavljen do banalnosti, u njemu je sadržano osnovno načelo svake književnosti - a to je intertekstualnost. Možemo taj pojam, koji je u znanstveni diskurs uvela Julija Kristeva, definirati pomalo poetski, pa reći: rukopisi među sobom razgovaraju. Ipak, posvetimo se egzaktnijem tumačenju te istaknimo da riječ tekst (textus) u latinskome znači „potka tkanja”. Dakle, tekst sačinjavaju niti, a one nisu ništa drugo doli dijelovi, elementi nekih drugih tekstova, književnih ili neknjiževnih, to nije važno. Jurij Lotman tako zaključuje da je književni tekst kodiran dvostruko: „prvi put jezičnim kodom, tj. posve općenito, gramatikom i leksikom jezika, drugi put estetičkim kodom, koji čini da tekst biva književnošću" (usp. Nöth 2004: 459). Slijedimo li Lotmanovo izlaganje reći ćemo da je književnost sekundarni sustav koji se gradi na osnovi prirodnog jezika svakidašnje komunikacije. ${ }^{1}$ Takvo je shvaćanje teksta implicirano i u Kristevinim izlaganjima o intertekstualnosti, koja je tim pojmom obilježila aktivan odnos teksta kao mreže znakovnih sustava sa sustavima označiteljskih praksi kulture iz koje taj tekst potječe (usp. Biti 2000: 224). Ono što je ključno u takvim razmišljanjima jest dokidanje strukturalističkog poimanja samodostatnosti teksta. Drugim riječima, tekst je uvijek uronjen u mrežu drugih tekstova, u mrežu citata čije je porijeklo nemoguće ustvrditi.

Uronjenost teksta u kontekst nije samo njegovo izvanjsko obilježje već i unutarnje, jer prilikom tumačenja (a svako je čitanje tumačenje) recipijent do značenja dolazi dekodirajući poruku na temelju vlastitog znanja, ili kako bi Umberto Eco rekao, vlastite enciklopedije, a ona je uvijek produkt

1 Lotmanovo određenje podsjeća na definiciju književnosti koju nam je dao Roman Jakobson, a prema kojoj je književnost „organizirani čin nasilja nad običnim govorom” (usp. Eagleton 1987: 10). 
kontingentnih utjecaja okoline. Time neminovno dolazimo do funkcije (de) konstruiranja teksta tijekom čitalačkog čina. Pratimo li, međutim, povijest književne teorije od devetnaestoga stoljeća pa do danas, odnosno od pozitivizma do poststrukturalizma, uvidjet ćemo da njezin interes $u$ pogledu interpretacije nije oduvijek bio usmjeren na diseminirajuće polje (kon)teksta. Uopćeno možemo reći da se pozitivizam zanimao za ličnost autora, strukturalizam za djelo, ${ }^{2}$ a teorija recepcije za čitatelja. Ono što je u svakom od tih interesa zajedničko jest da je svaki od njih imao točno određeni nukleus iz kojega je i prema kojemu se moglo ustvrditi značenjsko jedinstvo promatranog djela. Taj cilj je i danas sačuvan u gotovo svakoj interpretaciji, ali put kojim se do njega stiže obilježen je manjom mjerom jednostranošću interpretatorova pogleda. Gubitak nevinosti u postmodernizmu, koju je Eco duhovito opisao u pogovoru Imena ruže (usp. Eco 2004: 479-506), nije zadesio samo književnu produkciju, već i onu književnoteorijsku. Stoga je svaki autor koji drži do sebe primoran na neprestano osvrtanje na vlastito pismo ne bi li iz njega „izbrisao” i posljednji trag naivnosti te, po mogućnosti, istaknuo vlastitu samosvijest.

Jonathan Culler u svojoj kratkoj Književnoj teoriji poručuje da „interpretirati djelo znači ispričati priču o čitanju” (Culler 2001: 75). ${ }^{3}$ S obzirom na to da smo skloni književno djelo (tj. njegovu realizaciju) poimati kao slijed događaja u čitateljevoj svijesti, takva nam se gnomična definicija može učiniti uporabljivom. Problem se pak pojavljuje kada postavimo pitanje: tko je taj koji čita? Nije li on tek produkt neke zamršene mreže citata koja se tek naporom ostvaruje u nešto što nazivamo identitetom? Odgovor na to pitanje je pozitivan, a sam ,identitet” čitatelja otkriva nam se kao pokušaj „zatvaranja i fiksacije smisla” (Kaufmann 2006: 86). Zato nas ne iznenađuje Roland Barthes kada poručuje: „Ja nije nedužni subjekt koji prethodi tekstovima. Ja koje pristupa tekstu već po sebi je mnoštvo drugih tekstova, beskonačnih ili, točnije, izgubljenih kodova (kojih su korijeni nestali)" (prema Biti 1994: 142). Dakle, od kud god krenemo i kamo god idemo, nađemo se zapleteni u paučinu tekstualnosti. Tome je razlog što smo mi narativna bića, a literarnost našega uma (Turner 1996) omogućuje nam neprestano strukturiranje i prestrukturiranje sadržaja s

2 U smislu u kojem Roland Barthes razlikuje djelo od teksta, dakle u prijelazu sa strukturalizma na poststrukturalizam (Barthes 1971).

3 Sličan naputak čitamo i u njegovoj knjizi O dekonstrukciji: „Govoriti o značenju djela znači ispričati priču o čitanju" (Culler 1991: 30). 
kojima se susrećemo kako bismo osmislili sebe, ali i svijet u kojemu obitavamo. Slijedom razmišljanja V. Bitija - u matici beskonačne intertekstualnosti pojmovi identiteta, djela, komentara i naposljetku teksta erodiraju jedan za drugim da bismo na koncu shvatili da je drevno hermeneutičko pitanje: „Što ovaj tekst zapravo znači?” u potpunosti devalvirano. Na kraju ostaje zamijeniti ga „jedinim relevantnim analitičkim pitanjem”, a to je: „Što zapravo uvjetuje odnosno proizvodi njegovo značenje” (Biti 1994: 142-143)? Problem je jedino što na to pitanje zbog složenosti utjecaja nije moguće odgovoriti.

Time dolazimo do pojma neograničene ili beskrajne semioze. Pojam u današnjem značenju pripisujemo američkom semiotičaru Charlesu Sandersu Peirceu. Semiozu sačinjavaju tri elementa: reprezentamen (ili znak u užem smislu), designat ili referent (predmet na koji se znak odnosi) te interpretant koji ih povezuje (tj. značenje toga znaka). Prema Peirceu, znak je trostruka veza među znakom (u užem smislu), označenom stvari i spoznajom proizvedenom $u$ duhu. Neograničenost semioze otkriva se $u$ sukcesivnosti interpretanata. Naime, s obzirom na to da svaki znak stvara nekog interpretanta, a on je pak reprezentamen nekog daljnjeg znaka, taj se proces, u kojem se ne može ustvrditi ni „prvi” ni „zadnji” znak, nastavlja $\mathrm{u}$ beskraj. Vrijedi ipak istaknuti da je proces semioze samo potencijalno beskrajan jer nas „zahtjevi praktičnog života” (Nöth 2004: 64) primoravaju da taj proces prekinemo u korist ostvarenja komunikacije. Takvi zahtjevi nisu ništa manje potrebni ni prilikom tumačenja književnoga teksta. Jer spoznaja da je neki tekst moguće beskrajno tumačiti može nas uvjeriti da je riječ, kao što zaključuje W. H. Auden, o književnom tekstu, ${ }^{4}$ ali isto nas tako može odvesti u ono što U. Eco naziva "hermetičkom plovidbom nasumce” (usp. Eco 2003: 320-325). Stoga smo prilikom tumačenja primorani odrediti vlastite ciljeve i sredstva za njihovo ostvarenje. U suprotnom, kad bismo se prepustili hermetičkoj plovidbi nasumce, lutali bismo od značenja do značenja, od jedne veze do druge bez izgleda da ćemo ikada doći do kraja lanca sukcesivnosti. Dakle, tumačimo li neki tekst, potrebno je odrediti granice tumačenja, o čemu Eco raspravlja u istoimenoj knjizi. Pritom treba naglasiti da za Eca konstruiranje granice nije cilj nego sredstvo. Njime se ne dosežu konačna već samo situacijski plauzibilna rješenja u dijalektičkom odnosu u kojem konstruirana granica služi tek kao orijentir u trenutnom

4 „Jedan od znakova da knjiga ima književnu vrijednost jest i taj da se ona može čitati na nekoliko različitih načina" (Auden 2004: 106). 
razumijevanju. Osvrćući se na razmišljanja Jacquesa Derride prema kojem je tekst mašina koja proizvodi neizmjerno odgađanje, odnosno prema kojemu "tekst pati od toga što ga je napustio njegov autor i njegov referent" (Eco 2003: 324), Eco mu se izravno ne suprotstavlja već samo ukazuje na razlike u njihovim stavovima. Derridina težnja jest pokazati moć jezika, njegovu sposobnost govorenja više od onoga što je doslovno namjerio kazati, dok je Ecova, zaštititi značenje u konkretnoj situaciji tumačenja. Stoga koherencija teksta i čuvanje te koherencije za Eca predstavljaju granice interpretacije koje su konstrukt subjektivnih parametara. Tako postignuta (i shvaćena) konzistencija teksta i interpretacije ne poriču ispravnost postavki neograničene semioze kao ni Derridine dekonstrukcije, ali uspostavljaju osnove na kojima govor o književnosti, kao i sama komunikacija, postaju uopće mogući.

Ecu je stalo do uspostavljanja interpretacijske ekonomičnosti, a višak tumačenja do kojega bi neminovno došlo, slijedimo li lanac beskrajne semioze, rezultirao bi rasipanjem hermeneutičke energije. Upozorimo pritom da semiozi i nije cilj tumačenje već uspostavljanje veza. Pojam pak otvorenoga djela koji je Eco predstavio u knjizi istoga naslova (1962), tek naizgled upućuje da su „sva tumačenja moguća”, odnosno da su sve veze koje čitatelj uspostavi valjane. Kako u Granicama tumačenja sam navodi: reći da potencijalno tekstu nema kraja ne znači da svaki čin tumačenja ima sretan kraj (usp. Eco 2003: 14). Stoga je relativno lako reći koje je tumačenje pogrešno, dok je zaključiti koje je najbolje nemoguće. U procesu neograničene semioze moguće je prelaziti od svakog značenjskog čvorišta na neko drugo, ali ipak ne smije se zaboraviti da sve te prijelaze nadziru ona pravila povezivanja koja je povijest naše kulture na određeni način opravdala. I upravo se na tom tragu nazire snaga Derridine misli, njezina subverzivnost i politička moć. Drugim riječima, Ecov pristup tumačenju koji je ukorijenjen u pragmatici može nam biti koristan prilikom bavljenja književnim tekstovima (ili onima koje na taj način odlučimo promatrati); njime uspostavljamo granice i domete interpretacije, zaokružujemo tumačenja i kreiramo hermeneutičke krugove, dok Derridinim pristupom dobivamo korisno oruđe za propitivanje okoštalih struktura društvenog teksta. Tvrditi da u tekstovima nikada ne možemo ući u trag izvornoga značenja istovremeno je istinito koliko i beskorisno, međutim, tvrditi da je stanje društva, koje strukture moći nastoje prikazati „prirodnim”, konstrukt, to se već doima kao pokušaj izlaska iz uvriježenih obrazaca mišljenja (slično onome što je radio Roland Barthes u Mitologijama). Tako, 
primjerice, Terry Eagleton smatra da Derridinu dekonstrukciju trebamo razumijevati kao političku praksu, „pokušaj razaranja logike pomoću koje pojedini sustav mišljenja - a u sklopu s njime i čitav sustav političkih struktura i društvenih ustanova - održava svoju moć" (Eagleton 1987: 162). Sve dok smo uronjeni u mrežu tekstova uronjeni smo u beskrajno polje označavanja i značenjskih igara, tek nam neposredno tjelesno iskustvo omogućuje uporište u stvarnosti te tada pojmovi kao što su „istina”, „pravda”, „poštenje” i sl. ne djeluju trivijalno i semantički prazno. Utoliko je naš nemir veći kad kod Jeana Baudrillarda čitamo o ratovima koji se „nisu dogodili”. ${ }^{5}$

Kao slikovit primjer raskoraka između tekstualnoga konstrukta i zbilje koja ga je potaknula navest ćemo strip Pakao scenarista Alana Moorea i crtača Eddiea Campbella koji tematizira slučaj serijskoga ubojice Jacka Rasparača. U tom se stripu nudi viđenje događaja koji su potresali London potkraj 19. st., a na osnovu kojih je stvorena jedna od najpoznatijih priča o serijskome ubojici (unatoč činjenici da se njegov identitet nikada nije otkrio). Tako Mooreovo i Campbellovo djelo problematizira pitanje povijesti koja nastaje kao produkt konsenzusa između sudionika događaja čija je memorija uvijek fragmentarna te koji stoga nisu sposobni sagledati sliku u njezinoj cjelovitosti. Na samom kraju djela, u Dodatku II, čitamo da je broj interpretacija monstruoznih kasapljenja žrtava, tijeka policijske istrage te mogućeg identiteta slavnog ubojice $s$ vremenom toliko hipertrofirao da se izgubila veza sa stvarnim zločinima. Navedeno je dovelo do toga da su interpretacije počele jedna na drugu utjecati stvarajući tekstove ad infinitum. Međutim, mimo različitih tumačenja i „viđenja” istine, ostaje ono u što se ne može sumnjati - a to su izgubljeni životi ubijenih žena, pa na početku stripa čitamo: „Knjiga je posvećena Polly Nichols, Annie Chapman, Liz Stride, Kate Eddowes i Marie Jeannette Kelly. Vi i vaša smrt: jedino u to smo sigurni. Laku noć, dame" (Moore i Campbell 2008). Makar i u mrtvom, prvotno i neosporivo uporište značenja je u tijelu.

Kao što je na navedenu primjeru moguće razaznati, povijest teško može udovoljiti naizgled sasvim skromnom zahtjevu Davida Perkinsa prema kojem je njezina zadaća „predstavljanje i objašnjavanje prošlosti”

5 Dakako, aludiramo na poznate Baudrillardove eseje (ukupno tri) objedinjene pod naslovom La Guerre du Golfe n'a pas eu lieu u kojima je pisao o Zaljevskom ratu i njegovoj medijskoj prezentaciji 1991. godine (usp. Baudrillard 1995). 
(Perkins 1992: 13). Svako predstavljanje podrazumijeva odabir, a odabir ovisi o procjeni relevantnosti povijesnih činjenica samoga povjesničara. ${ }^{6}$ Objašnjenje pak tih činjenica je fluidni, pa i porozni prostor interpretacije koja kudikamo više zadovoljava definiciju performativnosti, negoli deskripcije. ${ }^{7}$ Nije stoga ni čudno da je povijest izgubila nekadašnji status objektivne znanosti te da ju je oštrica dekonstrukcijske kritike približila književnosti. Takvo što moglo bi navesti raspravu u smjeru problematiziranja degradacije statusa same znanosti, kada bi unutar različitih spisateljskih praksi postojala hijerarhija vrijednosti. Svodeći sve tek na tekst, suvremena je teorija takvo što izbjegla. Dekonstrukcija kao moćno oruđe (oružje?!) nepovjerenja i propitivanja, sredstvo je s kojim postaje moguće „obračunavati” se s danim istinama. Zagledavanje u mnoge od tih istina brzo ih razotkriva kao produkte kulture maskirane u prirodno stanje. ${ }^{8}$

\section{Kritika i žudnja za vlastitim jezikom}

Roland Barthes u knjizi Kritika $i$ istina tvrdi da „pisati znači već organizirati svijet, već misliti (naučiti jezik znači naučiti kako se na tome jeziku misli)" (Barthes 2009a: 27). Pisanje je drugim riječima preosmišljavanje poznatog, u našoj svijesti već strukturiranog. Kao što objašnjava Nelson Goodman, govoriti o nestrukturiranom sadržaju je nemoguće, jer sam "govor nameće strukturu, konceptualizira, pripisuje sadržaj” (Goodman 2008: 15). Kritika je pak pokušaj da se tekstom govori o tekstu. Književna kritika tako djeluje na dva pola: uspostavlja vezu s prototekstom (tekstom koji „interpretira”) te istovremeno uspostavlja vezu sa samom sobom kako bi u svakom trenutku opravdala (ili dokazala) vlastitu konzistentnost. Slijedimo li Barthesa, najkraća definicija kritike glasila bi: ona je perifraza (usp. Barthes 2009a: 61).

6 Kod Claudia Guillena čitamo: „Istoričari i filozofi istorije danas obično priznaju da ne postoji nešto što bi bio unapred dat predmet istorije. On postoji samo ukoliko su ga istoričari odabrali i uobličili za nas" (Guillen 1982: 382).

7 Treba li podsjećati na Nietzscheovu čuvenu misao o tome da ne postoje činjenice, već samo interpretacije; njome se bavi u djelu $O$ istini i laži u izvanmoralnom smislu, djelu s kojim nagovješćuje epohu relativizma.

8 Na ovome mjestu bismo mogli govoriti o metapripovjestima onako kako ih tumači JeanFrançois Lyotard, kao samu naraciju kojoj je funkcija pozakonjenje (usp. Lyotard 1990: 35). 
Prema Barthesu, kritičar je osoba koja udvostručuje smislove; osoba koja ponad prvotnog jezika djela stvara drugotni jezik suvisle povezanosti znakovlja (usp. Barthes 2009a: 55). Drugotnost je tu od osobita značaja, jer upravo elementom razlike koji se u kritičarskom diskursu realizira u odnosu na interpretirani predložak, djelo se „oplemenjuje” smislom koji odgovara kritičarevom tekstu. Barthes ističe: „kritičara ne ovjerava smisao djela, nego smisao onoga što o djelu kaže" (Barthes 2009a: 56). To ne znači da kritičar „mijenja” ili „izobličuje” značenje djela prema vlastitoj želji i nahođenju, već da je svaki diskurs o nečemu dodana semantička vrijednost u odnosu na ono o čemu se govori. Kada to ne bi bilo tako, onda bi - da je s uspjehom realiziran - Don Quijote Pierrea Menarda bio najuzornija književna kritika ikada napisana (usp. Borges 2000a).

Govoriti o nečemu znači iznevjeriti predmet o kojemu se govori. Istovremeno se udaljiti od njega, ali ga također i uramiti vlastitim znanjem i diskursom. Pojam diskurs priziva Michela Foucaulta koji tvrdi da svojstvo znanja nije ni „vidjeti ni pokazati, već interpretirati” (Foucault 2002: 59). Za dodati je da smo u proces interpretacije uronjeni već od samog početka procesa recepcije. Ipak, književna se kritika nalazi na višem stupnju od puke recepcije. Interpretacija koju se kritikom nudi ne služi toliko razumijevanju onoga na što se ona referira (promatrano djelo) koliko stvaranju konzistencije na razini hermeneutičkoga kruga kojega tvori. Pritom, dakako, značenja o kojima ona govori mora podržati samo djelo. Kao što Eco kazuje, tekst je moguće tumačiti na bezbroj načina, ali na kraju je tumačenje potrebno dokazati na osnovu promatranoga teksta te u slučaju da tekst „ne odobri” naše „najrazuzdanije pokušaje”, obavezni smo ustuknuti u svojoj hermeneutičkoj nakani (usp. Eco 2003: 34). Ono što pritom valja istaknuti jest da je tekst istovremeno predmet proučavanja, ali i parametar tumačenja (usp. Eco 2003: 11). Prostor slobode je u kritici, međutim, dovoljno velik da bi u njemu bilo mjesta za igru. Stoga nas ne iznenađuju interpretacije Slavoja Žižeka filmova koje nije pogledao, niti kritike glazbenih publicista o koncertima koji se nisu održali. Tomu je razlog što je kritičar, slijedom Barthesovih promišljanja, obilježen promjenom žudnje. Kritičar, naime, ne žudi za djelom, nego za vlastitim jezikom (usp. Barthes 2009a: 67). Time dolazimo do zaključka da se užitak u tekstu ne ostvaruje samo jednosmjerno, na polu recepcije, već i na polu produkcije (što ne isključuje i financijske motive u slučaju spomenutih glazbenih publicista koji pišu tekstove o neodržanim koncertima). 
Razmišljanjima o kritici kao djelatnosti igre i užitka približavamo se onome što Herbert Marcuse naziva estetskom dimenzijom. Podsjetimo, tim pojmom Marcuse označava čovjekove djelatnosti koje su suprotstavljene svijetu prisile, gospodarenja i podjarmljivanja, dakle onome što povezujemo s radom kao otudenom djelatnosti u klasnom društvu (usp. Marcuse 1981: 16). U nastavku ćemo pokazati da kritika, iako nastaje iz užitka stvaranja, svoje tradicionalno mjesto u sustavu književnosti ima zahvaliti prvenstveno valorizacijskoj svrhovitosti i uspostavljanju moći između sudionika književne komunikacije. Zapitat ćemo se koje je mjesto kritike u tržišnom sustavu rukovođenom načelima potrošnje i proizvodnje, te u vremenu koje se odreklo valorizacijskih sudova? Ili ih čak više nije u stanju donositi.

\section{Kritika na tržištu ili tržištem po kritici}

Više je hrvatskih književnih znanstvenika koji su svojim radom dali značajan obol teorijskom razmatranju književne kritike. Tako se raspravljanje o književnokritičkoj situaciji u domaćim okvirima treba dotaknuti barem trojice autora koji su svojim tekstovima postavili temelje daljnjih diskusija. Riječ je, dakako, o Svetozaru Petroviću koji je u studijama Kritika i djelo (1963) te Priroda kritike (1972) detronizirao uvriježenu podjelu unutar sustava znanosti o književnosti te jedino teoriju književnosti smatrao znanošću, dok povijest književnosti i književna kritika kod njega nisu imale taj status jer ne mogu udovoljiti kriteriju egzaktnog proučavanja književnosti. ${ }^{9}$ Drugim riječima, dok se teorija književnosti

9 „Književna kritika, zaključili smo, nije nauka, i neće to nikad postati. Doduše, ako se sami sebi činimo tako učeniji, možemo i nju, i njoj srodnu povijest književnosti - djelatnost građenja književnopovijesne vizije - smatrati dijelom nauke o književnosti. Tada, međutim, ne smijemo zaboraviti da smo riječi „nauka” pridali značenje koje nije uobičajeno. Kad tu riječ želimo upotrijebiti sasvim precizno, možemo njome označiti samo teoriju književnosti, proširenu - naravno - tako da obuhvati i metodologiju proučavanja književnosti, i srodne pomoćne grane poput tekstologije i literarno orijentirane filologije, i brojne egzaktne postupke studija književnosti koji tek u naše vrijeme dobivaju puno značenje i pravu važnost" (Petrović 1963: 133-134). Nešto kasnije Petrović citira jedan svoj stariji rad (iz 1959. godine) u kojemu zaključuje sljedeće: „Od statističkih je postupaka jednako besmisleno tražiti odgovor na pitanje, je li djelo vrijedno i zašto jest ili nije. Uostalom, književna kritika i proučavanje književnosti postoje već nekoliko tisuća godina, a nismo, kako se čini, još uvijek dobili (i nećemo vjerojatno nikada dobiti) ni jednu jedinu analizu, koja bi zaista nesumnjivo dokazala i prihvatljivo objasnila, da je neko književno djelo dobro (ili loše). Međutim, egzaktni nam postupci mogu pomoći, da realnije, neposrednije zagledamo u način kako književnost funkcionira, u uzroke, zbog kojih se djelo jednom 
bavi provjerljivim znanstvenim dokazivanjem, književna kritika operira u domeni subjektivnih vrijednosnih sudova, koji su kao takvi relativno lako interpretacijski opovrgljivi. Te je razlike u svojim radovima bio svjestan i Milivoj Solar (Pitanja poetike, 1971; Teorija književnosti, 1976; Književna kritika i filozofija književnosti, 1978), ali je ipak književnoj kritici pridavao tradicionalno mjesto u podjeli znanosti o književnosti. Time je Solar blizak trećem književnom znanstveniku, Vladimiru Bitiju, koji je u svojem ključnom tekstu o književnoj kritici (Škreb i Stamać 1998) sumirao spoznaje o predmetu ne samo ključnih domaćih već i svjetskih autora, ali ih i proširio vlastitim uvidima. Nama će pak u ovome radu biti poticajan jedan Bitijev drugi tekst koji problematizira funkcioniranje književne kritike u uvjetima potrošačkog društva, riječ je o tekstu pod naslovom Žanr i žar tranzicije (Hekman i Matičević 2005). S obzirom na to da se naš pogled na književnokritičku situaciju tiče suvremenosti, razdoblja od dvadesetak posljednjih godina $\mathrm{u}$ kojem su nastale bitne promjene na domaćoj književnoj sceni, Bitijevi će uvidi biti od znatne koristi.

Prije upuštanja u problematiziranje naslovom naznačene teme istaknimo da se pojam književna kritika koristi za djelatnost vrijednosnog prosuđivanja i njegove rezultate. Pritom je od osobite važnosti njezina posrednička uloga između djela i čitatelja. Kritika je ta koja uvjerava čitatelja u vrijednost nekoga djela, ili, pak, tu vrijednost osporava (usp. Solar 2007: 188-189). Iz navedenog proizlazi da se književna kritika uglavnom bavi djelima iz suvremenosti te da je stoga sinkronijska djelatnost i kao takva opozicija povijesti književnosti koja je neraskidivo povezana $s$ dijakronijskim pristupom u proučavanju. Antoine Compagnon je na sljedeći način sažeo razliku između književne kritike i povijesti: „Književna kritika izriče sudove ovakve vrste: »A je ljepše nego B«, dok književna povijest tvrdi: „C potječe od D”. Prva se trudi vrednovati tekst, druga objasniti ga” (Compagnon 2007: 18).

vremenu, jednom sloju publike ili jednom kritičaru sviđa, u suptilne odnose između strukture lirske pjesme i senzibilnosti čitaoca. Ti postupci mogu ohrabriti objektivno proučavanje književnosti, nauku o književnosti, koja će se odreći prava da o djelu izriče ocjenu, ali će pokušati da objasni fenomen umjetničkog jednako objektivno, jednako slobodna od sentimentalne fraze, kao što je - tek jučer - psihoanaliza počela da objašnjava fenomen ljubavi" (Petrović 1963: 179). 
O povijesti kao kontingentno uvjetovanu konstruktu koji je izgubio znanstveni autoritet prethodno smo raspravljali, ${ }^{10}$ stoga ćemo se na ovome mjestu posvetiti statusu suvremene kritike (ili: statusu kritike u suvremenosti). Ipak, vratimo se još jednom Compagnonu koji piše da se „književna kritika i književna povijest suprotstavljaju jedna drugoj kao unutarnji i vanjski pristup: kritika se usredotočuje na tekst a povijest na kontekst." Upozorili smo da je koncentracija na tekst kao odjelit entitet od sve druge zbilje suštinski nemoguća jer se moć jezika očituje u tome da govori više od onoga što je nakanio reći (usp. Eco 2003: 324). Situacija je identična i s kontekstom - on je sam po sebi tekst, s tom razlikom da ga nismo u mogućnosti čak ni formalno ograničiti (kao što je to slučaj s djelom). Kao korektiv i pojašnjenje izrečenog neka posluže Derridine riječi: „Ako upotpunjavanje više nema nikakva značenja, to nije zato što beskonačnost nekog polja ne može biti dosegnuta konačnim pogledom ili konačnim načinom obrade, nego zato što priroda tog polja - tj. jezik i konačni jezik - isključuju potpunost" (Derrida 1999: 218). Sačinjavanje granica (u Ecovu smislu riječi) konteksta djelatnost je odabira, čime se ponovno vraćamo na problematiku kontingentnosti.

To su teme koje nas vode do ključnog kriterija svakog odabira, a to je vrijednost. Kao što V. Biti tumači, vrijednosni je sud kontrastivne naravi, što znači da neko pripisano obilježje odvaja jedan entitet od drugih $\mathrm{s}$ obzirom na mjerilo uvedeno radi njihove usporedbe (usp. Biti 2000: 554). Međutim, sve dok nema osviještenih mjerila, ne može biti ni izbora među vrijednostima. Time se suočavamo s trima osobitostima naše suvremenosti koje je Milivoj Solar u svojim Predavanjima o lošem ukusu detektirao kao ključne za razumijevanje gubitka moći estetičkoga prosuđivanja: prevlast slike nad pojmom, prevlast sinkronije nad dijakronijom i nepreglednost količine informacija (Solar 2004: 21).

Da živimo u svijetu kojim dominiraju slike na ovome mjestu nije nužno dokazivati jer nas svakidašnje iskustvo uvjerava u istinitost te tvrdnje, ali Solarova teza o prevlasti slike nad pojmom odnosi se na posljedice takva stanja. Prema autoru ključna je posljedica toga slabljenje kritičkog mišljenja i nestanak ukusa. S obzirom na to da se mišljenje gradi u dijalek-

10 Tek se uzgred prisjetimo riječi J.-F. Lyotarda: „Znanost koja nije postigla legitimnost nije prava znanost, ona zapada na najniži stupanj, onaj ideologije ili oruđa moći" (Lyotard 2005: 55). Nešto kasnije u istoj knjizi Lyotard piše da je znanstvenik netko tko ima ideje i tko priča priče koje je obavezan provjeriti (usp. str. 89). 
tičkom odnosu kroz procese negacije i prihvaćanja, svijet slika u koji smo uronjeni, a koji je uvijek afirmativan, ${ }^{11}$ takvu mogućnost vremenom sve više dokida. Ako je sve sadržano u potvrdi, mišljenje ne može postojati jer se nema na što osloniti, a nema ni kamo napredovati. Nadalje, razlika između slike i teksta je $\mathrm{u}$ načinu kako ih percipiramo te $\mathrm{u}$ količini informacija koje putem njih možemo primiti. Dok sliku percipiramo simultano i za to nam je potreban tek trenutak (ona je uvijek atemporalna), tekst percipiramo sukcesivno, linearno. Slikom se u istom vremenskom odsječku može prenijeti neusporedivo više informacija nego tekstom. Ta nas razmatranja dovode do drugog Solarova zaključka, o prevlasti sinkronije nad dijakronijom. Uronjenost $\mathrm{u}$ permanentnu sadašnjost koja $\mathrm{u}$ sebe inkorporira elemente prošlosti prema slobodnom nahođenju (dobar je primjer modna industrija koja počiva na reciklaži starih, prethodno probranih trendova, koji se ponovno koriste u maniri pastiša i/ili patchworka), dovodi do toga da nestaje spoznaja o temporalnom karakteru promjena koje zahvaćaju stvari i pojave kojima smo okruženi. Ono što ostaje jest izloženost diktatu trendova. Time se ujedno dotičemo onoga što je Guy Debord u istoimenoj knjizi nazvao društvom spektakla. Kako Debord navodi: „Prva nakana vladavine spektakla bila je učiniti da nestane povijesna spoznaja općenito, a ponajprije gotovo sve informacije i svi razumni komentari o nedavnoj prošlosti" (Debord 1999: 184). U (post)modernom društvu upravo se to događa, a nepreglednost količine informacija, Solarov treći zaključak, uvelike pridonosi tom fenomenu. Iako Debord navodi da nestaju informacije, preciznije je reći da one hipertrofiraju te da time u svojoj nepreglednoj količini postaju konfuzne, kontradiktorne te na koncu nesagledive. Nekritička pak izloženost informacijama rađa ravnodušnost ${ }^{12}$ i pasivnost što je problem za neku drugu, opširniju raspravu.

Lyotard tvrdi da u „nedostatku estetičkih kriterija” ostaje moguće, a ujedno je i korisno, vrijednost djela mjeriti profitom koje ono donosi (usp. Lyotard 1990: 18-19). U spektaklu se, štoviše, „nedostatak estetičkih kriterija" i ne smatra nedostatkom, jer njihovo postojanje ili nepostojanje ima zanemariv učinak na stvarnu recepciju (a to je prodaja/potrošnja)

\footnotetext{
11 „Bez jezika, slike ne mogu ništa nijekati. Uzročnost i ini logični odnosi ne mogu se predstavljati slikovno. Slike ne mogu zapravo ništa tvrditi, pa shodno tomu zbiljski ni lagati" (Nöth 2004: 482).

12 „Svijesti, koja dopušta da bude svestrano informirana, sve postaje problematično i sve ravnodušno" (Sloterdijk 1992: 301).
} 
umjetničkih djela/kulturnih proizvoda. Odavno su Max Horkheimer i Theodor Adorno ustvrdili da se u kulturnoj industriji vrijednosni sudovi doživljavaju „ili kao reklama ili kao brbljanje” (Horkheimer i Adorno 1989: 152). Za dodati je da „brbljanje”, kao i svaka, pa i najnegativnija kritika, u medijskom okruženju postaje reklama. Ili, preciznije, u medijskom prostoru svako „brbljanje” ispunjava funkciju reklame. U nepreglednosti informacijskog kaosa ključna je vidljivost, a kritika nju, makar i kratkotrajno (dugotrajnost ionako nije poželjna), pruža onom djelu na koje se odnosi.

Već spominjani pripadnik Frankfurtske škole, Herbert Marcuse, zapisao je da kad „sredstva masovne komunikacije harmonično i često neprimjetno slijevaju umjetnost, politiku, religiju i filozofiju $s$ komercijalnim oglasima, ona dovode domene kulture na njihov zajednički nazivnik - na formu robe" (Marcuse 1989: 68). A svrha robe je njezina potrošnja. Da bi se, međutim, potrošnja ostvarivala u zadovoljavajućoj mjeri potrebno je njegovati stanovite kvalitete. Kod finskog sociologa Jukke Gronowa čitamo da su to: rasipnost, samoudovoljavanje i umjetna zastarjelost (usp. Gronow 2000: 22). Sve su to elementi koji hrane etiku zabave, hedonizma i permanentnog konzumerizma.

$\mathrm{Na}$ primjeru hrvatske književne scene od početka 21. stoljeća možemo detektirati sve spominjane malformacije do kojih dolazi kada zakoni tržišta počinju sve više utjecati na funkcioniranje kulturne proizvodnje. Zadržat ćemo se na jednom primjeru iz 2005. godine. Riječ je o „Biblioteci Premijera” koju je medijski koncern Europapress holding (EPH) pokrenuo tijekom ljetnih mjeseci navedene godine. U tjednom ritmu objavljeno je osam romana ${ }^{13}$ nekih tada već bivših pripadnika Festivala alternativne književnosti, poznatijeg pod akronimom FAK. ${ }^{14}$

13 Riječ je o sljedećim autorima i romanima: Ivo Brešan: Tri života Tonija Longina, Boris Dežulović: Jebo sad hiljadu dinara, Zoran Ferić: Djeca Patrasa, Miljenko Jergović: Gloria in excelsis, Jurica Pavičić: Kuća njene majke, Edo Popović: Dečko, dama, kreten, drot, Borivoj Radaković: Virusi, Ante Tomić: Ljubav, struja, voda \& telefon.

$14 \mathrm{Na}$ ovome mjestu nije potrebno ulaziti u analizu nastanka i raspada FAK-a, ali možemo reći da je tijekom svoga trajanja od 2000. pa do kraja 2003. godine obilježio domaću književnu scenu i jedan njezin dio učinio medijski atraktivnim. Pisci okupljeni oko akronima FAK bili su skloni realističkoj prozi, za što se u kritičarskom diskursu u to vrijeme uvriježio naziv „stvarnosna proza”. Medijska pak „atraktivnost” FAK-a doživjela je svoj vrhunac tijekom sukoba dosadašnjih suradnika koji su se vodili na stranicama vodećih dnevnih novina te koji su na koncu doveli do njegova samoinicijativnog gašenja. Proglas o gašenju FAK-a može se pročitati u: Rizvanović 2003. 
Romani su se mogli kupiti uz primjerak Jutarnjega lista po zanemarivoj cijeni, a ono što je na ovome mjestu ključno jest da se svaki roman na kioscima zadržavao samo jedan tjedan, dakle, dok ga ne bi zamijenio drugi roman iz pokrenute biblioteke.

Osvrćući se na lokalno stanje književnog polja, a između ostalog i na tzv. kiosk-izdavaštvo, Dean Duda je postavio važno pitanje o položaju književne kritike u kontekstu takve vrste hiperprodukcije. Duda se, naime, zapitao kako kritika može reagirati „kad proizvod koji pokušava predstaviti nestaje s obzora prije nego što je uopće predstavljen?" (Duda 2009: 417) Taj postupak ne potvrđuje samo da ritam tržišta i primat umjetne zastarjelosti otežavaju funkcioniranje posredničke uloge koju kritika tradicionalno ima, već da je kritika u takvoj konstelaciji naprosto suvišna. Tragom Debordovih razmišljanja može se zaključiti da je posrijedi promišljeni postupak dokidanja kritičkog glasa; situacionist tumači: glavni uzrok dekadencije mišljenja suvremenog čovjeka treba tražiti u činjenici da sav diskurs iskazan u spektaklu ne ostavlja mjesta za odgovor, a logika, dakle, i kritički stav, stvara se samo u dijalogu (usp. Debord 1999: 197). Tako je „Biblioteka Premijera" oprimjerila ono što je Solar zapisao u Predavanjima o lošem ukusu; u trenutku kada zavlada tržište, kritička recepcija nestaje, odnosno kritika mora biti zamijenjena apologijom (usp. Solar 2004: 83). Ipak, to nužno ne podrazumijeva neumjerenu hvalu svega objavljenog, već sukladno dosadašnjem izlaganju, da kritički glas u prostoru komercijalnih medija biva sveden na reklamnu funkciju. Jer kada kritičari nemaju vremena za pisanje tekstova kojima će argumentirati svoje stavove o pročitanom djelu, oni nužno pišu kratke osvrte koji se svode na formu vijesti o objavljenom, reklamnu obavijest.

U tom kontekstu, a i vezano za promicanje djela koja su objavljivali sudionici Festivala alternativne književnosti u vrijeme njegova trogodišnjeg trajanja, vrijedi spomenuti česte optužbe upućene književnoj kritičarki Jagni Pogačnik. Riječ je o kritičarki koja je u vrijeme pojavljivanja FAK-a na domaćoj književnoj sceni pisala književnokritičke osvrte $u$ Jutarnjem listu, novinama u tadašnjem vlasništvu medijskog koncerna Europapress holding. Na osnovu toga mnogi su je nazivali nekritičkom promotoricom fakovaca. Uvid u njezine tekstove, kao i knjige sabranih kritika (vidi: Pogačnik 2002 i 2006) koje su popraćene njezinim komentarima na domaću književnu scenu, otkriva da je ta optužba tek djelomično točna. Pojašnjenje; njezine kritike o djelima fakovaca nisu uvijek bile pozitivne, dapače, bilo je i vrlo negativnih, međutim, samo njihovo objavljivanje (pogotovo na 
spomenutom mjestu) ostvarivalo je funkciju promocije što je u skladu s tezom da se značaj kritike u potrošačkom društvu (prešutno) ne mjeri njezinim valorizacijskim, već tržišnim učinkom. Međutim, to nije ništa novo. Sam nastanak književne kritike, u povijesnom smislu, neraskidivo je povezan s trenutkom u kojem se uopće formira književno tržište. I Milivoj Solar i Vladimir Biti u svojim radovima (Solar 1978: 135; Biti 1998: 83; Biti 2005: 65) taj trenutak prepoznaju u koncu 18. stoljeća. Tada dolazi do funkcionalne stratifikacije organiziranoga društva, odnosno do odvajanja književne od religijskih, ćudorednih te znanstvenih normi, a književna kritika postaje „pozvana unijeti nekakav red u sve nepregledniju „šumu signala" kojom umjetnička književna produkcija zastrašuje potencijalne potrošače" (Biti 2005: 66).

Domaća je književna scena od 1990-ih do danas istovremeno bila poprište destrukcije brojnih tiskovina koje su pratile književnu produkciju (smanjivanje ili pak nestanak kulturnih rubrika iz dnevnih novina također je dobar primjer), kao i izdavača koji su na tu istu scenu donosili nove knjige. Ali također u promatranom razdoblju došlo je i do smjene generacija, kako one književnokritičarske, tako i one književnoumjetničke. Prestankom objavljivanja ključnih kritičara iz prethodnog razdoblja (primjerice B. Donat, I. Mandić, Z. Zima, V. Visković) upraznila su se mjesta koja u međuvremenu nisu popunjena. Ne zato jer nema novih autora koji bi bili na kvalitativnoj razini svojih starijih kolega, već zato jer ne postoji mjesto na kojem bi mogli kontinuirano objavljivati te se tako javnosti nametnuti kao prepoznatljivi glasovi. Za profiliranje novih kritičkih glasova potrebno je imati časopisnu i/ili novinsku platformu koja neće biti opterećena tržišnim interesima. S obzirom na smanjivanje ulaganja države u časopisnu produkciju (posljednjih godina svjedočimo gašenju važnih časopisa (primjerice Mogućnosti, Libra libera, Zarez), takvo što nije za očekivati. Suprotan primjer od toga je tiskovina koja je tržišno orijentirana te joj kao takvoj nije u interesu biti poligon za kritičko pismo, već za promociju izdavača i autora. Takvo određenje odgovara magazinu za knjige pod nazivom Best Book koji izlazi dvaput mjesečno kao prilog tjedniku Express od 2013. godine. U domaćim okvirima riječ je o vrlo dobroj informativnoj publikaciji koja donosi intervjue s domaćim i stranim autorima, prikaze novoobjavljenih knjiga te koja na koncu i ne pretendira na ništa više od onoga što pisanje o knjigama u tržišnim uvjetima treba biti, a to je reklama; bez cinizma se može reći da u zemlji u kojoj je čitalačka kultura ispod razine europskog prosjeka, takav cilj nije za obezvrijediti. 
Poput mode koja je glavni tržišni pokretač, i reklame su prvenstveno slike. Njihovo je osnovno obilježje to da su uvijek aformativne. Na ovome mjestu razmišljanja Jeana Baudrillarda postaju izrazito poticajna. Baudrillard tumači da je zanimljivost slike sadržana u njezinoj sposobnosti da kontaminira stvarno i da ga modelira sebi u korist; ona određuje stvarnost do onog stupnja da se „stvarno više nema vremena proizvesti kao takvo” (Baudrillard 2001: 156). Na primjeru „Biblioteke Premijera” mogli smo se osvjedočiti kako je stvarnosna proza u jednom trenutku postala hiperrealni tržišni proizvod.

\section{Zaključna razmatranja}

Svaka kritika u svojoj je biti pokušaj opravdanja ukusa njezina autora. Takva misao nužno dovodi u pitanje objektivnost svake valorizacije, ali tome i treba biti tako; objektivnost je potrebno neprestano propitivati (i raskrinkavati). Subjektivnost kritičkog glasa uostalom i jest razlog zbog kojega je Petrović zaključio da kritika nije znanstvena djelatnost te da ju kao takvu treba razlikovati od teorije književnosti. Samonametnuti zadatak da obrazovanjem baštinimo kulturnu tradiciju (kanon) te da pojedina umjetnička djela sagledavamo u širem kontekstu te iste tradicije tek je pokušaj da subjektivnu avanturu traženja uzora, dobrih i loših primjera, učinimo mjerljivom i usporedivom, prividno objektivnom. Tako se svaka (hinjena) objektivnost na koncu uvijek otkriva kao dobra argumentacija. Ta argumentacija pod neprestanim je pritiskom kontingencije koja oblikuje i sačinjava znanje kojim raspolažemo. Krhkost naših stavova o umjetnosti, lakoću njihova revidiranja, zorno oprimjeruje Borgesov tekst o Franzu Kafki i njegovim pretečama. Podsjetimo, osvrćući se na Kafkin opus Borges zaključuje da u njemu prisutni forma i ton postoje i u djelima autora koji su mu prethodili, ali koje upravo zahvaljujući Kafkinoj književnoj ostavštini možemo čitati na način da u njima pronalazimo duhovnu srodnost $s$ Kafkom. ${ }^{15}$ Dakle, naše spoznaje ponekad mogu imati i retrogradan učinak, ali čim se dotičemo retrogradnosti iz sinkronije ulazimo u područje

15 „(...) Ako se ne varam, ti raznovrsni primjeri koje sam nabrojio nalik su na Kafku; ako se ne varam, oni nisu svi slični međusobno. Ova druga činjenica vrlo je važna. U svakom je pojedinom od tih tekstova idiosinkrazija, više ili manje, kafkinska, ali da Kafka nije pisao, ne bismo je opazili; bolje reći: ona ne bi ni postojala. (...) Činjenica je da svaki pisac stvara svoje preteče. Njegovo djelo preinačuje naš pojam o prošlosti, kao što će preinačiti i budućnost" (Borges 2000b: 117-118). 
dijakronije, iz kritike u povijest (koja je prema Petroviću također daleko od znanosti o književnosti). Teško da drukčije i može biti, jer kao što je već rečeno, spoznaja nastaje u procesu, u dijalogu posredstvom kojega se formiraju kritički stavovi i stoga je kritika bez povijesne dimenzije nemoguća.

Problem suvremenosti je ne samo što mehanizmi kulturne industrije potiru promišljanje prošlosti, već i to što se pod pritiskom brzine smanjuje jedinica vremena u kojoj se uopće može ponuditi odgovor na trenutno stanje stvari (kao što je pokazano na primjeru „Biblioteke Premijera”). Ako se dokine vrijeme za mišljenje onda je uistinu svaki kritički glas koji pristaje sudjelovati u igri prema tim novim pravilima, rječnikom Adorna i Horkheimera, obična brbljarija. Takva kritika predstavlja tek jednu kariku u lancu neograničene semioze smještene na tržišnom polju. Ona, naime, označuje nešto drugo što je istovremeno i samo nešto drugo i tako u nedogled unutar lukrativnih i simboličkih interesa sudionika toga slijeda. Jer kao što znamo, sve što pronalazi svoje mjesto na tržištu, pa tako i knjige i kritike o njima, postaje proizvod, ali i znak u tržišnom procesu.

Slična razmišljanja Vladimira Bitija navode na zaključak da je književna kritika žanr tranzicije (Hekman i Matičević 2005). Kako autor objašnjava, riječ je o žanru koji ima moć preseliti „ne samo pojedine književne autore, već i autorske skupine pa i čitave generacije sa skučenih na unosne položaje i dispozicije u rasporedu kulturalnog polja". Također, kritika je i autotranzicijska djelatnost te u naznačenim uvjetima poslovnog partnerstva „recipročno uspinje i samoga kritičara po vrijednosnoj ljestvici kulturalnog, društvenog i ekonomskog kapitala" (usp. 67). Uistinu, lako je pokazati da većina autora vrlo brzo nakon početka bavljenja književnom kritikom pronađe drugi angažman. Pisanje književne kritike tako često posluži kao odskočna daska za neku bolje plaćenu profesionalnu poziciju. $\mathrm{Na}$ književnoj sceni poput naše, na kojoj je prostor za objavljivanje kritike skučen, taj fenomen ne iznenađuje. Posao kritičara je zahtjevan, iziskuje znatno vrijeme i neprestani rad na sebi, a pritom je valorizacija tog posla dok se savjesno obavlja - siromašna.

Nakon svega iznijetog moguće je ustvrditi da kritika koja se objavljuje $\mathrm{u}$ tiskanim medijima svojim većim dijelom više nije u stanju ostvarivati valorizacijsku i posredničku zadaću koja joj je bila tradicionalno pripisivana. Ona je, naime, prečesto interesno umrežena što je udaljuje od takvih ciljeva. To ne znači da kritike nema, ili pak da je loša, već da se njezin relevantniji dio preselio na druge medije, internet i radio. Primjerice, portal Booksa.hr 
ili pak radijska emisija Bibliovizor (urednica Gordana Crnković Raunić) zasigurno predstavljaju sam vrh onoga što se u Hrvatskoj objavljuje o domaćoj i stranoj književnoj produkciji. Književni blogovi također omogućuju prostor za pisanje kritičkih tekstova. Taj medij autoru pruža mogućnost brzog reagiranja na književna zbivanja, a nepostojanje uredničke supervizije otvara prostor za korištenje neformalnijeg jezika, slenga i sl. Navedeno je istovremeno i prednost i mana jer na koncu blogovi svjedoče o neujednačenoj kvaliteti tekstova koji često ne bi zadovoljili kriterije koji se stavljaju pred tiskana izdanja. Ipak, dokaz da iz kvantitete može nastati kvaliteta jest blog Knjiški moljac Božidara Alajbegovića. Posrijedi je blog kojega je autor pokrenuo 2004. godine te na kojem je objavljivao vlastite književne kritike, kao i prenosio vijesti koje se tiču književnosti, intervjue s piscima i dr. Alajbegović je vrlo brzo svoje pisanje o književnosti preselio na tiskane medije (časopisi Vijenac, Književna Rijeka, Val, Nova Istra...), a prema ustrajnosti kojom prati domaću i prijevodnu književnu produkciju u našim okvirima nema pandana. Zaključimo, spomenuti internetski portali i blogovi, kao i radijske emisije, iako potencijalno imaju široku publiku, ipak se na koncu obraćaju malom krugu recipijenata koji takve sadržaje ciljano prati. Stoga je kritika objavljivana na tim platformama često specijalistička te ne dopire do masovne publike na način kako su to nekoć činili tekstovi objavljivani u novinama. S druge strane, amaterizam koji je često prisutan kod književnokritičke produkcije na blogovima, sukladno svojoj etimologiji, svjedoči pak o ljubavi pojedinaca prema književnoj riječi. Oba se fenomena međusobno nadopunjuju te ujedno otklanjaju bojazan o eventualnoj smrti i krizi kritike o kojoj se često raspravlja.

Vrijedi podsjetiti da je Lyotard pišući o statusu znanja unutar postmodernog stanja zaključio da će znanje s vremenom poprimiti karakteristiku robe i time prestati biti samo sebi svrhom (usp. Lyotard 2005: 4). Prema autorovim razmišljanjima odnos dobavljača i korisnika znanja postaje odnos proizvođača i potrošača u kojemu se znanje vrednuje njegovom korisnošću u nekoj novoj proizvodnji. Primijenimo li njegova promišljanja na književnu kritiku (koja je specifičan oblik znanja) dolazimo do spomenutog lanca označivanja i razmjene pogonjenog tržišnim interesima. Suvišno je i napominjati da je sadržaj onoga što se prodaje, u našem slučaju knjiga i kritika o njima, irelevantan sve dok sustav funkcionira. Sukladno dosad iznijetom, takvi zaključci ne trebaju ni iznenađivati ni uzrujavati. Osvrnemo li se ponovno na Barthesovu knjigu Kritika i istina ustvrdit ćemo da svaki tekst, pa tako i onaj kritički, prvenstveno počiva na igri u jeziku, a 
da je zahtijevati od njega svrhovitost (u našem slučaju valorizacijsku i/ili posredničku) njegovo osiromašenje; dodat ćemo i: pristajanje na tržišnu logiku kojom se stvari mjere njihovom korisnošću. Kritika odmaknuta od takvih zahtijeva nužno se približava statusu poezije - kao najradikalnijem prostoru slobode u jeziku, a trenutno dominantna mjesta objavljivanja (radio i internet), kao i uzajamno podržavanje ta dva oblika pisma, potvrđuju skladnost njihove veze i vjeru u dobru budućnost (na margini).

\section{LITERATURA}

Auden, W. H. (2004) „Čitanje i pisanje”; preveo Tomislav Sabljak, u: Sabljak, Tomislav (ur.), Angloamerička kritika, Matica hrvatska, Zagreb, str. 105-131.

Barthes, Roland (1971) Književnost, mitologija, semiologija; preveo Ivan Čolović, Nolit, Beograd.

Barthes, Roland (2009a) Kritika $i$ istina; prevela Lada Čale Feldman, Algoritam, Zagreb.

Barthes, Roland (2009b) Mitologije; prevela Morana Čale, Pelago, Zagreb.

Baudrillard, Jean (1995) The Gulf War Did Not Take Place; preveo Paul Patton, Indiana University Press, Bloomington \& Indianapolis.

Baudrillard, Jean (2001) Simulacija i zbilja; prevela Gordana V. Popović, Jesenski i Turk - Hrvatsko sociološko društvo, Zagreb.

Biti, Vladimir (1994) Upletanje nerečenog: književnost, povijest, teorija, Matica hrvatska, Zagreb.

Biti, Vladimir (1998) „Književna kritika”, u: Škreb, Zdenko i Stamać, Ante (ur.), Uvod u književnost. Teorija, metodologija, Nakladni zavod Globus, Zagreb, str. 75-105.

Biti, Vladimir (2000) Pojmovnik suvremene književne i kulturne teorije, Matica hrvatska, Zagreb.

Biti, Vladimir (2005) „Žanr i žar tranzicije”, u: Hekman, Jelena i Matičević, Ivica (ur.), Hrvatska književna kritika. Teorija i praksa, Matica hrvatska, Zagreb.

Borges, Jorge Luis (2005a) Pierre Menard, pisac Don Quijota, u: Izmišljaji; preveo Milivoj Telećan, Zagrebačka naklada, Zagreb, str. 38-52.

Borges, Jorge Luis (2000b) Kafka i njegove preteče, u: Druga istraživanja; preveo Marko Grčić, Zagrebačka naklada, Zagreb, str. 115-118. 
Calvino, Italo (2010) „Za koga se piše? (Hipotetična polica za knjige)”; prevela Natalija Nikolić, u: Europski glasnik, br. 15.

Compagnon, Antoine (2007) Demon teorije; prevela Morana Čale, AGM, Zagreb.

Culler, Jonathan (1991) O dekonstrukciji: teorija i kritika poslije strukturalizma; prevela Sanja Čerlek, Globus, Zagreb.

Culler, Jonathan (2001) Književna teorija: vrlo kratak uvod; preveli Filip i Marijana Hameršak, AGM, Zagreb.

Debord, Guy (1999) Društvo spektakla \& Komentari društva spektakla; preveo Gordan Vujasinović, Arkzin d. o. o., Zagreb.

Derrida, Jacques (1999) „Struktura, znak i igra u obradi znanosti”; preveo Miroslav Beker, u: Beker, Miroslav (ur.), Suvremene književne teorije, Matica hrvatska, Zagreb, str. 208-222.

Duda, Dean (2009) „Tranzicija i 'problem alata': bilješke uz lokalno stanje književnog polja”, u: Quorum, br. 5-6 (128-129, sv. 100).

Eagleton, Terry (1987) Književna teorija; prevela Mia Pervan-Plavec, SNL, Zagreb.

Eco, Umberto (2003) Granice tumačenja; prevela Milana Pilepić, Paideia, Beograd.

Eco, Umberto (2004) Napomene uz „Ime ruže”; prevela Morana Čale, u: Ime ruže, Globus media, Zagreb, str. 477-506.

Foucault, Michel (2002) Riječi i stvari, preveo Srđan Rahelić, Golden marketing, Zagreb.

Goodman, Nelson (2008) Načini svjetotvorstva; preveo Damjan Lalović, Disput, Zagreb.

Gronow, Jukka (2000) Sociologija ukusa; prevela Sandra Ivčević, Naklada Jesenski i Turk - Hrvatsko sociološko društvo, Zagreb.

Guillen, Claudio (1982) Književnost kao sistem; preveo Tihomir Vučković, Nolit, Beograd.

Horkheimer, Max i Adorno, Theodor (1989) Dijalektika prosvjetiteljstva; prevela Nadežda Čačinović-Puhovski, „Veselin Masleša” - „Svjetlost”, Sarajevo.

Kaufmann, Jean-Claude (2006) Iznalaženje sebe: jedna teorija identiteta, preveo Marko Gregorić, Izdanja Antibarbarus, Zagreb. 
Lotman, Jurij Mihajlovič (2001) Struktura umjetničkog teksta; prevela Sanja Veršić, Alfa, Zagreb.

Lyotard, Jean-François (1990) Postmoderna protumačena djeci; prevela Ksenija Jančin, August Cesarec, Zagreb.

Lyotard, Jean-François (2005) Postmoderno stanje; prevela Tatjana Tadić, Ibis grafika, Zagreb.

Marcuse, Herbert (1981) Estetska dimenzija; preveli B. Hudoletnjak, B. Brujić i dr., Školska knjiga, Zagreb.

Marcuse, Herbert (1989) Čovjek jedne dimenzije; prevela Branka Brujić, „Veselin Masleša” - „Svjetlost”, Sarajevo.

Moore, Alan i Campbell, Eddie (2008) Pakao: melodrama u šesnaest činova; prevela Tatjana Jambrišak, Fibra, Zagreb.

Nietzsche, Friedrich Wilhelm (1999) O istini i laži u izvanmoralnom smislu; preveo Damir Barbarić, Matica hrvatska, Zagreb.

Nietzsche, Friedrich Wilhelm (2003) Radosna znanost, preveo Davor Ljubimir, Demetra, Zagreb.

Perkins, David (1992) Is Literary History Possible?, The Johns Hopkins University Press, Baltimore and London.

Petrović, Svetozar (1963) Kritika i djelo, Zora, Zagreb.

Petrović, Svetozar (1972) Priroda kritike, Liber, Zagreb.

Pogačnik, Jagna (2002) Backstage, Pop \& pop, Zagreb.

Pogačnik, Jagna (2006) Proza poslije FAK-a, Profil International, Zagreb.

Rizvanović, Nenad (2003) „FAK (is) OFF!”, u: Slobodna Dalmacija, 14. 12.

Sloterdijk, Peter (1992) Kritika ciničkoga uma; preveo Boris Hudoletnjak, Globus, Zagreb.

Solar, Milivoj (1971) Pitanja poetike, Školska knjiga, Zagreb.

Solar, Milivoj (1976) Teorija književnosti, Školska knjiga, Zagreb.

Solar, Milivoj (1978) Književna kritika i filozofija književnosti, Školska knjiga, Zagreb.

Solar, Milivoj (2004) Predavanja o lošem ukusu, Politička kultura, Zagreb.

Solar, Milivoj (2007) Književni leksikon, Matica hrvatska, Zagreb.

Turner, Mark (1996) The Literary Mind, Oxford University Press, New York - Oxford. 
SUMMARY

Saša Stanić

(IM)POSSIBILITIES OF LITERARY CRITICISM TEXTS AND THEIR PLACE ON THE MARKET

The introductory part of the paper tackles several issues related to the interpretations of literary works under the influence of poststructuralist and deconstructionist theories in the literary science. The paper also focuses on the issue of the status of literary criticism during the reign of spectacles and market. In the context of contemporary reality, the existence of texts (in the broad sense of the word) cannot be compared to what we have already witnessed in the entire history of literacy. The underlying theses are supported by examples from the contemporary Croatian literature and media, as well as literary criticism publications in print, on the Internet and radio.

Key words: interpretation; literary criticism; value; contingency; society of the spectacle; market 